\title{
ANNUAL REPORT OF THE CONSERVATION COMMITTEE
}

The 75th anniversary year report presented at the Charleston, South Carolina meeting was so comprehensive in coverage that this 1964 report can limit itself to reporting on current matters and viewing a few perennial problems in slightly different perspective.

It is growing increasingly doubtful that a piecemeal attempt to keep the Earth productice and attractive can succeed. Almost any reading of current analyses of conservation needs - whether in the perpetuation of threatened species, environmental pollution, the control of depredations by birds, legislation, or whatever-will reflect the intricate and often obdurate socioeconomic conditions that influence all decisions in this allocation of priorities to resource use which we call conservation. Our nation of nearly 200 million people, if it is to exercise its tremendous new technological power without crowding all other forms of life from the landscape, needs a maturity and a sense of humility that is today anything but characteristic of the United States. This is the challenge to education.

It is therefore appropriate to call particular attention to the fine basic studies into the state of our material resources conducted in recent years by Resources for the Future, Inc., of Washington, D.C. These physical and economic appraisals and projections are fundamental to sound work in almost all land utilization. Fortunately, also, these studies are now being presented in a new series of brief popular reports. With the basic studies well along, RFF now wants to stimulate public discussion in these areas (Clawson, 1963). The Conservation Foundation of New York is also playing a valuable role in providing ecologically oriented discussions of many problems.

\section{LAND-USE PROBLEMS}

To appreciate their impact, the magnitude of modern regional management schemes must be visualized in terms of Rampart Dam and the Trinity River projects. The Alaska dam would inundate 9 million acres, creating a reservoir larger than Lake Erie. The Trinity River project, near Galveston, Texas, calls for "full development and beneficial public use of the water and related land resources of the Trinity River Basin." It is the first of a series of comprehensive land-use and development programs that would harness every one of the few waterways that nourish the Texas coast. It is obvious that such drastic remakings of the landscape will affect regional birdlife, enhancing conditions for a few species, but bringing disaster to many others unless the needs of a balanced wildlife population are specifically considered in the planning stage. Another such project is the proposal for a new regional water plan for the Southwest which includes two large dams at Marble and Bridge Canyons. The Marble Canyon dam would back water into the Grand Canyon National Park. Attempts to make the desert bloom, we too often forget, have a high price tag.

Economic and political pressures on the Department of the Interior squeezed the Kenai National Moose Range (Alaska) in two during 1963. Some 290 square miles were excluded from the refuge to allow intensive lumbering and oil and gas development, but even this did not satisfy Senator Gruening, who wanted 715 square miles. There would seem to be two object lessons in this development. "Kenai's difficulties began in 1958, when in an effort to get along with people, the department amended its regulations to permit oil and gas leasing on more than $90 \%$ of the stratified rock in the moose range certified by the U. S. Geological Survey as having potential. The department was under no mandate to open the moose range.

"But industrialization and human invasion of the moose range on a large scale is now accomplished fact. Belatedly ... the department now admits that 'Although operations 
have been carefully controlled to minimize destructive effects, and the oil companies have exhibited a high degree of cooperation, long-term scarring effects to the environment, the disturbance of wildlife, pollution dangers to fisheries and waterfowl waters, increased fire hazards, and human occupancy foreign to a natural habitat has resulted in serious detriment to the range's original objectives, invalidating earlier thoughts to the contrary.' 'Thoughts to the contrary' congressional records of several years ago make clear, were not the thoughts of biologists and interested conservationists. They were the thoughts of the politicians and petroleum interests and those who sought to appease them" (Poole, 1963).

In August 1963 Carl W. Buchheister, President of National Audubon Society, wrote to President Kennedy protesting a Budget Bureau proposal that the Hawaiian Islands National Wildlife Refuge be transferred to the State of Hawaii. This refuge includes famous Laysan Island, home of the endemic Laysan Duck, the drepanid Psittirostra, albatrosses, etc.; and Nihoa, home of the Miller-bird (Acrocephalus). Not too happily received in Washington, the protest was nevertheless timely and the U.S. Fish and Wildlife Service is at long last now in the process of doing something for this chain of islands (Buchheister, 1964).

Still very much worth fighting for is the Kentucky Woodlands National Wildlife Refuge which is seriously threatened by a Tennessee Valley Authority "Land-Betweenthe-Lakes National Recreation Area" in Kentucky and Tennessee. At the November 1963 convention of the National Audubon Society, Roger Tory Peterson challenged Dr. Edward C. Crafts, Director of the new Bureau of Outdoor Recreation, to "coordinate" these federal approaches to recreation in such a way as not to impinge on existing wildlife refuges. He said, "To me, coordination-which is one of BOR's assigned responsibilities-means avoiding conflict and overlapping in programs, and it is obvious that if BOR is to do a constructive job it must find new recreational opportunities without itself destroying existing wildlife values, and help prevent other agencies from trampling on these values.... If this kind of unilateral development can continue in our government, BOR will be superfluous from the start" (Peterson, 1963).

It is with some relief that conservationists received news of the Atomic Energy Commission's cancellation of "Project Chariot" in June 1963. The project had withdrawn a million acres of tundra in the Cape Thompson, Alaska area and proposed the experimental blasting out of a harbor. Rumor had it that the project was made necessary by the test-ban treaty between the U.S. and U.S.S.R., since the AEC's earth-moving contractors had been idled thereby. Some good biological studies of the area were a desirable by-product.

Wilderness.-"Howard Zahniser, 58, scholarly, gentle, widely loved executive director of the Wilderness Society, principal leader of the movement to secure enactment of a national wilderness conservation law, died peacefully at his home in Hyattsville, Maryland early on the morning of May 5. Prospects had never looked brighter for final Congressional action on the wilderness bill. The House Public Lands Subcommittee had completed hearings on the bill the previous week, and its leaders were speaking hopefully of early agreement on an acceptable, compromise measure" (Callison, 1964b).

\section{HABITAT POLLUTION}

Pesticides.-Twenty-five years from now, when the present debacle involving pesticides policy is looked back upon as an embarrassing chapter in the history of the age of technology, 1964 may stand out as the turning point in our return to sanity.

It was, unfortunately, the year that Rachel Carson died (14 April) of cancer at age 56. 
Perhaps the generation that does this looking back will know more about the role of chemical insult to replicating cells that today is only one of many clues to this disease of civilization.

On 15 May 1963 President Kennedy's Science Advisory Committee had issued its anxiously awaited report on the Use of Pesticides (Weisner, 1963). Industry spokesmen and agricultural officials quickly declared it "vague" and "unsatisfactory on many points." The rest of us were delighted that it had moved so far in recognizing the gravity of the situation and courageously advocated, in its Recommendation No. B 5, "elimination of the use of persistent toxic pesticides" as the goal of official policy. This is now a basic document.

Testifying before a senate subcommittee on 22 April 1964, Roger Tory Peterson again warned that food-chain poisoning was a serious threat to such end-of-the-chain fish-eaters as the Bald Eagle and the Osprey, among others, since it has been found that in both these raptors, eggs that fail to hatch contain significant amounts of DDT and DDE (Ames, 1964).

The scope of this problem, and the biggest news of the year, is obvious in the belated publicity given massive fish kills that have plagued the lower Mississippi River basin for three or four winters. This at last brought the U.S. Public Health Service into the middle of the pesticides controversy. The USPHS said that the insecticide endrin was responsible for these fish kills, but the manufacturer of endrin denied this and accused the bureaucrats of major scientific blundering. The case was unfortunately complicated by the fact that a manufacturing plant at Memphis, Tennessee had apparently dumped endrin wastes in the river. The Department of Agriculture gladly accepted USPHS testimony on this score since this allowed them to juggle the issue of environmental contamination resulting from "approved" agricultural uses of endrin. The accused industry, of course, denied all.

During April and May 1964 the Agricultural Research Service held a series of hearings on the question of revising the registration of endrin, aldrin, and dieldrin. The official attitude seemed to be "violations have been alleged, but even though we don't think anything is wrong, we're willing to be democratic and listen to complainants." Secretary Freeman finally announced that "none of the evidence presented at the hearings - or at a four-state conference in New Orleans-was scientifically adequate to justify withdrawal of endrin, aldrin or dieldrin for farm use."

Meanwhile, though the Public Health Service was apparently having trouble getting a special $\$ 800,000$ appropriation for a continuation of the studies on fish kills in the Mississippi and other rivers, the USDA was said to be seeking $\$ 85,000,000$ to "field monitor, on a scientific basis, the normal use of pesticides on farms and forests." Senator Ribicoff's subcommittee decided to inquire into why "science" seemed to be marching off in so many directions at once.

This was also the year when Philip Marvin, a chemical manufacturer turned ornithological analyst, launched a hoax since given wide endorsement and distribution by various farm magazines, chemical trade publications, and by no less eminent a biochemist than Dr. Thomas H. Jukes in the pages of American Scientist (Jukes, 1963).

Mr. Marvin's analysis of bird population data from Audubon Field Notes' Christmas counts purported to show that there had been a population explosion among birds, not only despite the increasing use of chemical insecticides, but apparently because of it (Marvin, 1964) ! Dr. Frank E. Egler fortunately helped take American Scientist off the hook (Egler, 1964), but it is impossible to counter the false impressions which were broadcast by farm magazines and the newspapers who copied them. 
Even so, new trends in official policy can be seen in New Hampshire Governor John W. King's 3 April 1964 directive asking all his state agencies to stop using DDT as an insecticide. In New York, the State Department of Conservation directed that no DDT be used in treating state forests that include lake trout watersheds, and a bill was passed setting up a Pest Control Board. On 7 May Secretary Udall directed the several bureaus and offices of the Interior Department to use pesticides "in a manner fully consistent with the protection of the entire environment. The guiding rule for the Department shall be that when there is a reasonable doubt regarding environmental effects of the use of a given pesticide . . . no use should be made."

\section{MIGRATORY BIRD HUNTING}

One continues looking in vain for the scientific justification of such unlimited bags as as that imposed on the Common Merganser by the State of Washington in 1963. Protecting fish hatcheries, which may be a special problem in Washington, is not sufficient cause for declaring an unlimited open season on a fish-eating bird. The U.S. Fish and Wildlife Service's regional director (Northeast) John S. Gottschalk led the way in a 19 March 1964 directive to all hatchery managers in his region requiring (1) dependence on nonlethal methods of control as a first step, (2) consultation with a professional depredations control agent if necessary, and (3) application for a special permit from the Regional Office to use lethal control methods where none other could be shown to be effective. Copies of the directive were sent to all other regional directors by Mr. Gottschalk, himself a fisheries biologist.

The difficulty of holding the line on waterfowl limits during these years of low water levels on the breeding grounds, and low productivity, was made apparent when Congressman T. A. Thompson of Louisiana called an open hearing in Washington 18 July "to find out if duck hunters have been given full consideration." $\mathrm{He}$ also called on Wildlife Service officials to stand ready for questioning by his Subcommittee on Fisheries and Wildlife. Since these two quizzes barely preceded the National Waterfowl Advisory Committee meeting in Washington, at which season length and bag limit are discussed, the intent of these unexpected hearings was obvious (Callison, 1963). These events point up the importance of alert conservation groups to counter political pressures for unwarranted relaxations in the annual regulations.

\section{ENDANGERED SPECIES}

Raptors.-The National Audubon Society's cooperative study of Bald Eagle populations continues as planned and interim reports are made at the Society's annual conventions (Sprunt, 1963). It is expected that a full-scale report on the California Condor studies of the past 2 years will be made at the Tucson, Arizona convention on 7 November 1964.

Dr. Walter R. Spofford, who studied the Golden Eagle problem in Texas and New Mexico during the past two winters, reported on the first phase of these studies at the Audubon Convention in Miami (Spofford, 1963). He reported that "The shoot-off of Golden Eagles in the Texas-New Mexico sheep and goat ranching country, which became regular and drastically efficient with the employment of gunners shooting from airplanes, has resulted in the destruction of over 20,000 Golden Eagles between 1942 and 1962. These were not resident eagles, as some ranchers believed, but migratory eagles from northern parts of the continent congregating upon southern wintering grounds." Heavy pressure continues on Secretary Udall to remove the restrictions on the use of airplanes to control eagle depredations (Callison, 1964a). 
Kites.-The discovery, in 1963, that Florida Everglades Kites were using the Loxahatchee National Wildlife Refuge, southeast of Lake Okeechobee, led to the observation of at least 15 kites there during the 1964 breeding season (A. S. Sprunt, IV, in correspondence). The initiative of Gilbert Cant deserves commendation. He convened an Emergency Committee for the Everglades Kite in May 1964, and his petition to Secretary Udall led to "closing to entry" that portion of the refuge being used by the kites.

Attwater's Prairie Chicken.-The publication of Lehmann and Mauermann's (1963) status review was an important catalyst to action in attempting to save this Gulf Coast race of the Greater Prairie Chicken from extirpation. An $85 \%$ decline in numbers since 1937 has brought the population down to some 1,335 birds! "In October, 1964 Richard H. Pough, acting for the Nature Conservancy, and Val Lehmann negotiated an option to buy 3428 acres for $\$ 364,000$. The full purchase price remains to be subscribed" (Buchheister, 1964).

Whooping Crane.-The 1963 production of seven young birds was a pleasant surprise to everyone, because aerial reconnaissance had uncovered nothing by way of breeding territories. In April 1964, also, the New Orleans Zoo provided two eggs to the Wildlife Service. These were hatched successfully at the private aviary of John J. Lynch, a Service biologist at Lafayette, Louisiana. The two young subsequently died, however. In a further, somewhat belated move to improve on the production of the existing captive flock, the lone San Antonio Zoo bird was brought to New Orleans, but no mating occurred.

On 15 November 1963 the Wildlife Service distributed Wildlife Leaflet 456 on Special Permits, enunciating a new policy which would make the Service a partner in an expanded program of artificial propagation of migratory game birds, perhaps even including the Whooping Crane and the Eskimo Curlew. In April 1964 the Service announced what appeared to be a commitment, rather than a proposal, to take eggs of wild Whooping Cranes from the northern breeding grounds in 1965 in an attempt to start a new captive flock. The National Audubon Society's deep reservations about such attempts were voiced in Audubon Magazine (Clement, 1964).

Eskimo Curlew.-Observers on the Texas coast, especially in the Galveston Island area, failed to find migrants in the spring of 1963 and 1964, as they had between 1959 and 1962.

\section{CONTROL OF BIRD POPULATIONS}

On 20 October 1959 representatives of ornithological and conservation organizations in the New York City area held a public meeting to protest the U.S. Navy's plan to continue killing albatrosses at Midway Island, in the mid-Pacific, because these birds were a hazard to radar patrol aircraft using this atoll as an operating base. As a result of this meeting, the Navy was induced to put off killing birds until recommendations made by the U.S. Fish and Wildlife Service to reduce the hazard had been fully implemented.

In late 1963 it became obvious that the Navy, not satisfied with an $85 \%$ reduction in bird-plane strikes, proposed to eliminate some 20,000 more albatrosses. Protesting this failure to consult in advance with all interested conservation groups, the National Audubon Society was invited to send its President to Midway at the expense of the Navy to evaluate the hazard and observe the steps being taken to reduce it. The Society (Buchheister, 1964) thereupon recognized the need of some control but made a number of suggestions for improving the welfare of Midway's albatross population that should, if developed, help counterbalance the heavy losses which have been imposed on this population in the past two decades. 
The appearance of the report of Secretary Udall's Advisory Board on Wildlife Management, "Predator and Rodent Control in the United States," on 9 March 1964, is a landmark in the continuing fight to keep control programs under control. The report is basic reading for everyone in the least interested in this multifaceted problem - to ornithologists as well as others-because it discusses the bird control problem and because many mammal control programs affect birds, especially raptors, indirectly.

Last year's report provided a two-page review of the bird control problem. It ended on the theme that here was a challenge to ornithological science. And so it is, of course. One of the obstacles to the public discussion of these matters, and to obtaining continuing support for so mundane an effort in science, is the popular notion that we already know all about birds.

Fortunately, there remains a very lively awareness of the basic nature of research needs among many of the professionals in our federal and state services who must cope with the man-bird relation. A good example is the recent action of the Department of Natural Resources in the State of Washington. They have initiated a field study to determine the status of "birds as forest protection agents." Almost all the northern European nations, as well as the Soviet and our friends in Canada, are far in advance of the United States in this area of research and application. Perhaps the very success of our chemical pesticides industry since World War II has blinded us to the needs and opportunities in this area of natural insect control.

There is, however, a real danger in doing anything but a thorough and perceptive job of investigation and experimentation. Population biology is a subtly complex challenge, and if premature discouragement with current attempts should lead to abandoning the program, this fundamental approach might be set back another generation.

Ornithologists need reminding that our own U.S. Fish and Wildlife Service pioneered this approach at the turn of the century and, under the leadership of one of the finest scientists it has ever attracted-W. L. McAtee-was making great strides in demonstrating the role of birds in controlling insects (Clement, 1960). The exigencies of World War II, and the subsequent population explosion, unfortunately shifted interest to quantitative efficiency in agriculture, creating the pesticide dilemma and multiplying the conflict between man and birds. The U.S. Department of Agriculture, which led us into this dark alley, now seeks $\$ 85,000,000$ to investigate what really happens to pesticides they have enthusiastically induced the farmer to use these 20 years past. It would make good sense to spend a fraction of this amount investigating how we can fit agriculture back into the ecosystem instead of allowing it to anastomose like a cancer.

Fortunately, again, though federal research in this area was shelved some 20 years ago, others have continued probing (Pimentel, 196la,b) and the future holds as much promise as it ever did. If you think such approaches are as promising as the investment we now make on the space race or other billion-dollar ventures, you had better help fight for the rounded effort suggested here. Congressional appropriations do not come from reasonable deliberation so much as from competitive haggling over how the pie shall be sliced.

The committee owes thanks to Dr. John W. Aldrich and Erwin W. Pearson of the U.S. Fish and Wildlife Service, who sent thoughtful comments. Ours was a "lame duck" session, and the chairman had to assume full responsibility for selection, emphasis, and wording. There was not time to review the manuscript.

\section{LITERATURE CITED}

Ames, Peter, and Gerald S. Mersereau

1964 Some factors in the decline of the Osprey in Connecticut. Auk, 81 (2):173185. 
Buchheister, Carl W.

1964 The president reports to you. Audubon Mag., 66(1):18.

Callison, Charles H.

1963 Ducks and pressures. Audubon Leader's Conserv. Guide, 4(14) (15 July).

$1964 a$ The Texas counter attack against Golden Eagle. Audubon Leader's Conserv. Guide, 5(6) (15 March).

$1964 b$ Howard Zahniser. Audubon Leader's Conserv. Guide, 5(10) (15 May).

Clawson, Marion

1963 Land for Americans. Rand McNally \& Co.

Clement, Roland C.

1960 Birds and insect control. Plants and Gardens, 16(3):95-96.

1964 The Whooping Crane: today and tomorrow. Audubon Mag., 66(2):74-77. Egler, Frank E.

1964 Pesticides - in our ecosystem. Am. Sci., 52(1):110-136.

Jukes, Thomas H.

1963 People and pesticides. Am. Sci., 51:355-362.

Lehmann, V. W., and R. G. Mauermann

1963 Status of Attwater's Prairie Chicken. J. Wildl. Mgmt., 27 (4) :712-725.

Marvin, Philip H.

1964 Bird numbers increase during pesticide years. Croplife, (May), pp. 8-11.

Peterson, Roger Tory

1963 The impact on wildlife. A Florida Notebook, pp. 52-55 (Proceedings Nat. Audubon Soc. convention, Miami, 11 Nov.).

Pimentel, David

1961a An ecological approach to the insecticide problem. J. Econ. Entom., 54(1): $108-114$.

$1961 b$ Species diversity and insect population outbreaks. Annals Entom. Soc. of Am., 54(1):76-86.

Poole, Daniel A. (ed.)

1963 Kenai Moose Range in squeeze. Nat. Resources Council, 6(18):127 (exec. news service).

SPOFFORD, W ALTER R.

1963 The Golden Eagle in the trans-Pecos and Edwards Plateau of Texas. A Florida Notebook, pp. 8-10 (Proceedings Nat. Audubon Soc. convention, Miami, 9 Nov.).

Sprunt, Alexander IV

1963 Continental Bald Eagle project, progress report no. III. A Florida Notebook, pp. 2-7 (Proceedings Nat. Audubon Soc. convention, Miami, 9 Nov.) .

Weisner, Jerome B. (Chairman)

1963 Use of pesticides. Report of the President's Science Advisory Committee, Washington, D.C. (15 May), 24 pp.

\author{
WOS Conservation Committee \\ Roland C. Clement, Chairman \\ Walter W. Dykstra \\ Daniel A. Poole
}




\section{$2 \mathrm{BHL}$ Biodiversity Heritage Library}

Clement, Roland C, Dykstra, Walter W, and Poole, Daniel A. 1964. "Annual Report of the Conservation Committee." The Wilson bulletin 76(3), 306-312.

View This Item Online: https://www.biodiversitylibrary.org/item/214514

Permalink: https://www.biodiversitylibrary.org/partpdf/209132

\section{Holding Institution}

American Museum of Natural History Library

\section{Sponsored by}

BHL-SIL-FEDLINK

\section{Copyright \& Reuse}

Copyright Status: In copyright. Digitized with the permission of the rights holder.

Rights Holder: Wilson Ornithological Society

License: http://creativecommons.org/licenses/by-nc-sa/4.0/

Rights: https://biodiversitylibrary.org/permissions

This document was created from content at the Biodiversity Heritage Library, the world's largest open access digital library for biodiversity literature and archives. Visit BHL at https://www.biodiversitylibrary.org. 